\title{
Kadınların Serviks Kanseri ve Taraması İle İlgili Sağlık İnançlarının Değerlendirilmesi
}

\author{
Gülcan ULUDAĞ ${ }^{1}$, Zerrin GAMSIZKAN ${ }^{2}{ }^{2}$, Mehmet Ali SUNGUR ${ }^{3}$
}

\section{ÖZ}

Amaç: Bu çalışma, kadınların serviks kanseri ve taraması hakkındaki tutum ve davranışları ile ilgili sağlık inançlarının değerlendirilmesi amacıyla yapılmıştır.

Gereç ve Yöntemler: Bu prospektif çalışmaya Düzce Üniversitesi Sağlık Uygulama ve Araştırma Merkezi Aile Hekimliği Polikliniği’ne Ocak - Mart 2019 tarihleri arasında başvuran ve çalışma kriterlerine uyan 360 kadın dahil edilmiştir. Verilerin toplanmasında 'Rahim Ağzı Kanseri ve Pap smear Testi Sağlık İnanç Modeli Ölçeği' ve 'Hasta Bilgi Formu' kullanılmıştır.

Bulgular: Çalışmadaki katılımcıların yaş ortalaması 42,54 \pm 10,13 (min:20-maks:65)’tür. Katılımcıların \%37,2'si $(\mathrm{n}=134)$ iç Pap smear testi yaptırmamış, bunların \%35,1'i $(\mathrm{n}=47)$ ihtiyaç duymadığı $)^{\prime}$ ve şikayeti olmadığ için testi yaptırmadığını belirtmiştir. Katılımcıların \%23,3 (n=84)'ünün ailesinde/ çevresinde serviks kanseri olduğu ve ailesinde/çevresinde serviks kanseri olan katılımcıların olmayanlara kıyasla Pap smear işlemi yaptırma oranlarının daha yüksek olduğu bulunmuştur ( $\mathrm{p}=0,017)$. Katılımcıların Rahim ağzı kanseri önemseme/ciddiyet $(\mathrm{p}=0,963)$, Rahim ağz1 kanseri duyarlılık $(\mathrm{p}=0,897)$ ve Rahim ağzı kanseri sağlık motivasyonu $(\mathrm{p}=0,370)$ puanlarının Pap smear testini yaptırmama nedenlerine göre anlamlı farklılık göstermediği görülürken Pap smear yarar/motivasyon ve Pap smear engeller puan ortalamalarının Pap smear testini yaptırmama nedenlerine göre istatistiksel olarak anlamlı farklılık gösterdiği saptanmıştır (her iki $\mathrm{p}<0,001$ ).

Sonuç: Çalışmadaki katılımcıların serviks kanseri ve taraması hakkında bilgi düzeyi arttıkça olumlu sağlık davranışlarına yönelimlerinin de artış gösterdiği görülmüştür. Bu nedenle tarama testlerinin kullanımını arttırmak amaçlı eğitim etkinliklerinin düzenlenmesi gerekmektedir.

Anahtar Kelimeler: Sağlık inanç modeli; serviks kanseri; tarama testleri.

\section{Evaluation of Women's Health Beliefs about Cervical Cancer and Screening}

\begin{abstract}
Aim: This study was conducted to evaluate the health beliefs of women about their attitudes and behaviors about cervical cancer and screening.

Material and Methods: This prospective study included 360 women who met the study criteria and applied to Düzce University Health Practice and Research Center Family Medicine Polyclinic between January - March 2019. Data were collected using 'Cervical Cancer and Pap Smear Test Health Belief Model Scale' and 'Patient information form'.

Results: The mean age of the participants was $42.54 \pm 10.13$ (min: 20-max: 65). 37.2\% ( $\mathrm{n}=134)$ of the participants had never had a Pap smear test before and $35.1 \%(n=47)$ of these participants stated that they did not have the test because they did not need the test or any complain. It was found that $23.3 \%(n=84)$ of the participants had cervical cancer in their family / around, and Having Pap smear tests rates were higher in participants with cervical cancer in their family/ around than in those without $(\mathrm{p}=0.017)$. While cervical cancer care/ severity ( $\mathrm{p}=0.963)$, cervical cancer sensitivity $(\mathrm{p}=0.897)$ and cervical cancer health motivation $(\mathrm{p}=0.370)$ scores did not differ significantly according to the reasons for not having a Pap smear test, It was found that the mean scores of Pap smear benefit/ motivation and Pap smear barriers showed a statistically significant difference according to the reasons for not having the Pap smear test (both $\mathrm{p}<0.001)$.
\end{abstract}

1 T.C. Sağlık Bakanlığı İliç İlçe Devlet Hastanesi, Erzincan, Türkiye

2 Düzce Üniversitesi, Tıp Fakültesi, Aile Hekimliği AD, Düzce, Türkiye

3 Düzce Üniversitesi, Tıp Fakültesi, Biyoistatistik ve Tıbbi Bilişim AD, Düzce, Türkiye 
Conclusion: In the study; as the knowledge level of the women in cervical cancer and screening increased, their tendency towards positive health behaviors increased. Therefore, training activities should be organized to increase the use of screening tests.

Keywords: Health belief model; cervical cancer; screening tests.

\section{GIRIŞ}

Günümüzde ülkemiz gibi diğer ülkelerde de kanser sıklığ giderek artmakta, etkin ve küratif bir tedavinin olmaması dolayısıyla kanserden korunmanın sağlığı koruma bağlamında en önemli basamak olduğu kabul edilmektedir. Kanser nedenli ölümlerin azaltılabilmesi için erken tanı önemli olup kanser tarama programlarının düzenli bir şekilde devam etmesi gerektiği belirtilmektedir (1). Bu amaçla Sağlık Bakanlığının kanser tarama çalışmaları gelişerek devam etmekte; gerek toplum sağlığ aile sağlığı merkezlerinde periyodik kanser taramalarının yapılması konusunda eğitimler düzenlenmektedir (2). Primer görevlerinden bir tanesi koruyucu hekimlik olan Aile Hekimliği disiplininde; sistemde çalışan aile hekimleri ve uzmanlık eğitimi alan aile hekimliği asistanları çalıştıkları eğitim kurumlarında kanser tarama programları ile ilgili eğitimler almaktadırlar. Alınan eğitimler içeriğinde işlemlerin uygulanmasının yanı sıra halkın bu konudaki farkındalığını ve bilgi düzeyini arttırmak da yer almaktadır.

Dünyada kadınlarda görülen kanser türlerinde dördüncü sirada yer alan serviks kanseri, tarama testleriyle erken evrede saptanabilen bir kanser türüdür. Serviks kanserinin erken tespitinde Pap Smear testi kullanılmaktadır. Ülkemizde Pap smear yaptırma davranışının sosyal ve kültürel faktörlerden etkilendiği ve kadınların test yaptırma oranlarının istenilen düzeyde olmadığı dikkate alındığında, servikal kanser konusunda farkındalık ve bilgiyi artırmanın, test yaptırmada etkili sağlık inançlarını göz önünde bulundurarak kadınların Pap smear yaptırmalarına katkı sağlayıcı çalışmaların ve araştırmaların yapılmasının aile hekimlerinin görevleri arasında yer aldığı gözlemlenmektedir (3).

Victoria Champion tarafindan meme kanseri ve taramaları ile ilgili alg1 ve inanç düzeylerini tespit etmek amaciyla 1984 yılında geliştirilen, 1993, 1997 ve 1999 yıllarında revize edilen 'Sağlık İnanç Modeli Ölçeği' kişinin sağlığa ilişkin eylemleri yapmaya veya yapmamaya neyin sebep olduğunu ve sağlık davranışlarının sergilenmesinde etkili olanı tanımlamak amacıyla kullanılan en eski ve en çok bilinen sağlık davranış modellerinden birisidir. Champion'un 'Sağlık İnanç Modeli Ölçeği’ çeşitli ülkelerden araştırmacılar tarafından kendi kültürlerine uygunluğu açısından geçerlilik güvenirlilik çalışmaları ve diğer kanser türlerine uyarlama çalışmaları yapmışlardır (4). Ülkemizde de 2010 yılında Güvenç ve arkadaşları(5) sağlık inanç modeli ölçeğini serviks kanseri ve pap smear testi için uyarlayarak, geçerlilik ve güvenirliliğini almışlardır. Yapılan literatür incelemesi doğrultusunda koruyucu hekimlik kapsamına giren servikal kanser tarama testini yaptırma ve yaptırmama nedenlerinin tespit edilmesi ve bu nedenleri etkileyebilecek faktörlerin tanımlanması aile hekimliği koruyucu sağlık hizmetlerine katkı konusunda yönlendirici olacağı düşünüldü.

Bizim bu çalışmadaki amacımız, Düzce Üniversitesi Aile Hekimliği polikliniklerine herhangi bir sebeple başvuran evli kadın hastaların servikal kanser ve pap smear yaptırma konusundaki sağlık inançlarını etkileyen faktörleri tespit etmek ve halkın kanser taraması konusundaki bilgilerini ve farkındalıklarını arttırmaya yönelik bir araç olarak kullanmaktır. Elde edilen sonuçlarla da kadınların pap smear yaptırma davranışlarının olumlu yönde yönlendirmek amaçlı hekimlerin yeni yol haritaları çizmelerine yardımcı olmaktır.

\section{GEREÇ VE YÖNTEMLER}

$\mathrm{Bu}$ araştırma, kadınların serviks kanseri ve taraması ile ilgili sağlık inançlarının 'Sağlık İnanç Modeli' yaklaşımı ile değerlendirilmesi amacıyla tanımlayıcı ve kesitsel nitelikte bir çalışmadır. Araştırma Düzce Üniversitesi Tıp Fakültesi Aile Hekimliği Polikliniği'nde Ocak-Mart 2019 tarihleri arasında yürütülmüştür. Araştırma evrenini, Düzce Üniversitesi Tıp Fakültesi Aile Hekimliği Polikliniği' ne başvuran 19-65 yaş aralığındaki evli/boşanmış kadınlar oluşturmuştur.

Örneklem seçimine gidilmeyerek verilerin toplandığ tarihlerde polikliniğe başvuran, dahil olma ve dişlama kriterleriyle uyumlu, çalışmaya katılmayı kabul eden tüm evli/boşanmış kadınlar çalışmaya dahil edilmiştir.

Veri Toplama Araçları;

Hasta Bilgi Formu; Katılımcıların sosyo-demografik özellikleri, serviks kanseri ve Pap smear testi ile ilgili bilgi ve davranışlarını belirlemeye yönelik 18 sorudan oluşmaktadır.

Rahim Ăgzı Kanseri ve Pap Smear Testi Să̆lık Inanç Modeli Ölçeği; Victoria Champion tarafından meme kanseri taramalarında kullanılmak üzere geliştirilen ölçek (1984), Güvenç ve arkadaşları tarafından 2010 yılında serviks kanseri ve taraması için uyarlanmış, geçerlik ve güvenilirlik çalışmaları yapılmıștır. Ölçek 35 maddeden oluşmakta ve beş alt boyutu bulunmaktadır. Bu alt boyutlar; Pap smear yarar ve motivasyon algisi (8 madde), Pap smear engeller algısı (14 madde), Rahim ağzı kanseri önemseme ve ciddiyet algısı ( 7 madde), Rahim ağzı kanseri duyarlılık alg1sı (3 madde) ve Rahim ağzı kanseri sağlık motivasyonu algısı (3 madde)'dır. Ölçek 1-5 arasında değişen 5'li likert tipi ölçekleme yöntemi kullanılarak değerlendirilmiştir. Puanlama 'kesinlikle katılmiyorum' (1), 'katılmıyorum' (2), 'kararsızım' (3), 'katılıyorum' (4), 'kesinlikle katılıyorum' (5) olarak değerlendirilmektedir. Ölçeğin alt boyutları ayrı değerlendirilmektedir. Ölçekte kullanılan boyut sayısı kadar puan elde edilmektedir. Alt boyutlar için alınabilecek en yüksek ve en düşük puanlar; Pap smear yarar/motivasyon algısı için 8-40 puan, Pap smear engeller algısı için 14-70 puan, rahim ağzı kanseri önemseme/ciddiyet algısı için 7-35 puan, rahim ağzı kanseri duyarlılık alg1sı için 3-15 puan, rahim ağzı kanseri sağlık motivasyon algısı için 3-15 puan arasında değişmektedir. Puanların yükselmesi sağlık motivasyonunun, duyarlılığın ve önemseme/ciddiyetin arttığını ifade etmektedir. Alt ölçeklerden engel algısı, Pap smear tarama davranışıyla negatif olarak ilişskilidir. 
Etik Prosedür; Çalışmaya başlamadan önce Düzce Üniversitesi Klinik Araştırmalar Etik Kurulu'ndan 17.12.2018 tarih ve 2018/232 say1lı etik kurul izni alınmıştır. Araştırma kapsamındaki katılımcılardan haklarının korunması amaciyla, verileri toplamaya başlamadan önce araştırmayla ilgili bilgi verilerek sözlü onamları alınmış, çalışma süresi ve amacı konusunda bilgilendirme yapılmıştır. Ankete yanıt veren katılımcıların kimlikleri gizli tutulmuştur. Araştırmada kullanılan bilgiler, araştırma dışında kullanılmamış olup, sonuçlar sadece bilimsel dilde paylaşılmıştır.

\section{İstatistiksel Analiz}

Araştırmada istatistiksel analizler SPSS v.22 paket programı ile yapılmış anlamlılık düzeyi 0,05 olarak dikkate alınmıştır. Normallik varsayımı Shapiro-Wilk testi ve varyans homojenliği varsayımı Levene testi ile incelenmiştir. Sürekli değişkenler için tanımlayıcı istatistikler ortalama \pm standart sapma, kategorik değişkenler için frekans ve yüzde şeklinde verilmiştir. Grup karşılaştırmaları One-Way ANOVA testi ile yapılmış ve anlamlı farklılık saptanan durumlarda LSD çoklu karşılaştırma testi kullanılmıştır. Kategorik değişkenler arası ilişkinin incelenmesinde Pearson ki-kare testi kullanılmıştır.

\section{BULGULAR}

Çalışmada Düzce Üniversitesi Aile Hekimliği Polikliniği'ne 1 Ocak 2019 - 31 Mart 2019 tarihleri arasında başvuran ve dahil edilme, dışlama kriterlerine uyan 360 kadın katılmıştır. Kadınların yaşı 20 ila 65 arasında değişmekte olup, yaş ortalaması 42,54 $\pm 10,13$ dür. Katılımcıların sosyodemografik özelliklerine göre katılımcıların \%62,2'si (n=224) 30-49 yaş aralığındadır. Çalışmaya katılan kadınların \%11,1'i $(n=40) 30$ yaş alt grubunda, \%28,3'ü $(\mathrm{n}=102)$ 30-39 yaş grubunda, \%33,9'u (n=122) 40-49 yaş grubunda, \%23,1'i $(n=83)$ 50-59 yaş grubunda ve \%3,6'sı $(n=13) 60$ yaş ve üzeri grubundadır. Katılımciların \%48,9'u (n=176) ilkokul mezunu olduğunu, \%71,9'u (n=259) çalışmadığını, 94,7 ( $\mathrm{n}=341)$ 'si ise evli olduğunu belirtmiştir (Tablo 1).

Katılımcıların \%62,8 ( $\mathrm{n}=226)$ 'i daha önce en az $1 \mathrm{kez}$ Pap smear testini yaptırdığını belirtirken, \%37,2 ( $n=134)$ 'si daha önce bu testi hiç test yaptırmamıştır. Pap smear testini yaptırdığını belirten katılımcıların \%42,9 (n=97)'u $1 \mathrm{kez}, \% 32,3$ (n=73)'ü $2 \mathrm{kez}, \% 10,6(\mathrm{n}=24)$ 's1 3 kez, \%14,2 (n=32)'si 4 ve üzeri sayıda test yaptırdığını belirtmiştir. Pap smear testinin en son yaptırıldı ğı zamana yönelik olan soruya Katılımcıların \%37,2 (n=134)'si 'hiç yaptırmadım' şeklinde cevap verirken, \%22,8 (n=82)’i son 1 y1l içinde, \%26,1 (n=94)'i son 5 yıl içinde, \%6,4 $(n=23)$ 'ü 5 yıldan uzun süre önce yaptırdığını, \%7,5 $(n=27)$ 'i ise hatırlamadığını belirtmiştir. Testi yaptırma nedenine yönelik sorulan soruda test yaptırmış olan katılımciların \%50 (n=113)'si kadin hastalıkları nedeniyle yaptırdı ğını belirtirken, $\% 33,2(n=75)$ 'si doktor önerisiyle, \%14,6 (n=33)'sı sağlık kontrolü için, \%2,2 $(n=5)$ 'si ailede kanser öyküsü olduğu için yaptırdığını belirtmiştir. Testi yaptırmama nedenine yönelik sorulan soruya ise yaptırmamış olan katılımcıların $\% 23,9$ $(n=32)$ 'u bilgi sahibi olmadığ 1 için, \%35,1 (n=47)'i

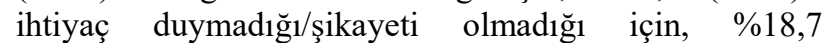
(n=25)'si muayeneden çekindiği/korktuğu için, \%4,5 $(n=6)$ 'i risk altında olmadığını düşündüğü için yaptırmadığını belirtirken, \%17,9 $(n=24)$ 'u diğer etmenler nedeniyle yaptırmadığını belirtmiştir (Tablo 2).

Tablo 1. Katılımcıların sosyodemografik özelliklerine göre dağılımları $(\mathrm{n}=360)$

\begin{tabular}{|l|c|c|}
\hline Yaş grupları & Sayı (n) & Yüzde (\%) \\
\hline$<30$ & 40 & 11,1 \\
\hline $30-39$ & 102 & 28,3 \\
\hline $40-49$ & 122 & 33,9 \\
\hline $50-59$ & 83 & 23,1 \\
\hline$\geq 60$ & 13 & 3,6 \\
\hline Öğrenim durumu & & \\
\hline Okuryazar & 17 & 4,7 \\
\hline İlkokul & 176 & 48,9 \\
\hline Ortaokul & 48 & 13,3 \\
\hline Lise & 72 & 20,0 \\
\hline Üniversite & 47 & 13,1 \\
\hline Meslek & & \\
\hline Çalışmıor & 259 & 71,9 \\
\hline İşçi & 33 & 9,2 \\
\hline Memur & 25 & 6,9 \\
\hline Serbest meslek & 24 & 6,7 \\
\hline Emekli & 19 & 5,3 \\
\hline Medeni durum & & \\
\hline Evli & 341 & 94,7 \\
\hline Boşanmış/dul & 19 & 5,3 \\
\hline
\end{tabular}

Tablo 2. Katılımciların Pap smear testi yaptırma ve yaptırmama durumu ve nedenleri $(n=360)$

\begin{tabular}{|l|r|r|}
\hline Smear testi yaptırma & \multicolumn{1}{|c|}{$\begin{array}{c}\text { Sayı } \\
\text { (n) }\end{array}$} & \multicolumn{1}{c|}{$\begin{array}{c}\text { Yüzde } \\
\text { (\%) }\end{array}$} \\
\hline Evet & 226 & 62,8 \\
\hline Hayır & 134 & 37,2 \\
\hline $\begin{array}{l}\text { Smear testi } \\
\text { yaptırma sayısı (n=226) }\end{array}$ & & \\
\hline 1 & 97 & 42,9 \\
\hline 2 & 73 & 32,3 \\
\hline 3 & 24 & 10,6 \\
\hline$\geq 4$ & 32 & 14,2 \\
\hline Smear testini en son yaptırma zamanı & \\
\hline Hiç yaptırmadım & 134 & 37,2 \\
\hline Son 1 yılda & 82 & 22,8 \\
\hline Son 5 yılda & 94 & 26,1 \\
\hline 5 yıldan fazla & 23 & 6,4 \\
\hline Hatırlamıyorum & 27 & 7,5 \\
\hline Smear testi yaptırma nedeni (n=226) & 75 & 33,2 \\
\hline Doktor önerisi & 33 & 14,6 \\
\hline Sağlık kontrolü için & 5 & 2,2 \\
\hline Ailede kanser öyküsü & 113 & 50,0 \\
\hline Kadın hastalıkları için & 32 & 23,9 \\
\hline Smear testi yaptırmama nedeni (n=134) & \\
\hline Bilgi sahibi olmamak & 24 & 17,9 \\
\hline İhtiyaç duymamak/ şikayeti olmamak & 47 & 35,1 \\
\hline Muayeneden çekinmek/ korkmak & 25 & 18,7 \\
\hline Risk altında olduğunu düşünmemek & 6 & 4,5 \\
\hline Diğer & 24 & \\
\hline \multicolumn{2}{|r|}{} & \\
\hline
\end{tabular}

Katılımcıların \%23,3 (n=84)'ü ailesinde ve/veya çevresinde serviks kanseri olduğunu belirtmiştir. Ailesinde/çevresinde serviks kanseri olanların Pap smear testi yaptırma oranı $(n=62, \% 73,8)$, olmayan kadınların 
yaptırma oranından $(\mathrm{n}=164, \% 59,4)$ yüksek bulunmuştur ( $p=0,017$; Tablo 3).

Tablo 3. Katılımcıların ailesinde/çevresinde serviks kanseri olma durumuna göre Pap smear testi yaptırma durumları $(n=360)$

\begin{tabular}{|c|c|c|c|}
\hline & \multicolumn{2}{|c|}{$\begin{array}{c}\text { Ailede/Çevrede serviks } \\
\text { kanseri olma durumu }\end{array}$} & \multirow{2}{*}{$\mathbf{p}$} \\
\cline { 1 - 3 } $\begin{array}{c}\text { Smear yaptırma } \\
\text { durumu }\end{array}$ & Var & Yok & \\
\cline { 2 - 3 } & $\mathbf{n ~ ( \% )}$ & $\mathbf{n ~ ( \% )}$ & \multirow{2}{*}{$\mathbf{0 , 0 1 7}$} \\
\hline Evet & $62(73,8)$ & $164(59,4)$ & \\
\hline Hayır & $22(26,2)$ & $112(40,6)$ & \\
\hline Toplam & $84(100)$ & $276(100)$ & \\
\hline
\end{tabular}

Ölçek alt puanları ayrıntılı incelendiğinde Pap smear testi yaptırmayan Katılımcıların Pap smear yarar motivasyon ve Pap smear engeller puanları bakımından Pap smear testini yaptırmama nedenleri arasında istatistiksel olarak anlamlı farklılık olduğu saptanmış olup $(p<0,001)$; Rahim ağzı kanseri önemseme/ciddiyet $(\mathrm{p}=0,963)$, Rahim ağz1 kanseri duyarlılık $(\mathrm{p}=0,897)$ ve Rahim ağzı kanseri sağlık motivasyonu $(\mathrm{p}=0,370)$ puanlarının Pap smear testini yaptırmama nedenlerine göre istatistiksel olarak anlamlı farklılık göstermediği saptanmamıştır. Bilgi sahibi olmadığı için Pap smear testini yaptırmadığını belirten kadınların Pap smear yarar motivasyon puanının diğer gruplardaki kadınların puanından anlamlı derecede düşük olduğu görülmüştür. İhtiyaç duymadığı için Pap smear testini yaptırmadığını ifade eden kadınların Pap smear engeller puanının ise yaptırmama nedenini bilgi sahibi olmamak ve çekinmek/korkmak olarak ifade eden kadınların puanından anlamlı derecede düşük olduğu belirlenmiştir (Tablo 4).

Tablo 4. Katılımcıların Pap smear testini yaptırmama nedenlerine göre 'Rahim Ağzı Kanseri ve Pap smear Testi Sağlık İnanç Modeli Ölçeği' alt boyut puan ortalaması $\left(\mathrm{n}=110^{*}\right)$

\begin{tabular}{|c|c|c|c|c|c|}
\hline \multicolumn{2}{|l|}{ Alt boyut } & $\mathbf{n}$ & Ortalama & $\begin{array}{c}\text { Standart } \\
\text { sapma }\end{array}$ & $\mathbf{p}$ \\
\hline \multicolumn{6}{|c|}{ Pap Smear Yarar ve Motivasyon } \\
\hline \multirow{4}{*}{$\begin{array}{l}\text { Yaptırmama } \\
\text { nedeni }\end{array}$} & Bilgi sahibi olmamak & 32 & $27,50^{\mathrm{a}}$ & 3,43 & \multirow{4}{*}{$<\mathbf{0 , 0 0 1}$} \\
\hline & İhtiyaç duymamak & 47 & $32,30^{b}$ & 3,67 & \\
\hline & Çekinmek/korkmak & 25 & $31,92^{b}$ & 3,33 & \\
\hline & Risk altında görmemek & 6 & $33,50^{b}$ & 2,17 & \\
\hline \multicolumn{6}{|c|}{ Pap Smear Engeller } \\
\hline \multirow{4}{*}{$\begin{array}{l}\text { Yaptırmama } \\
\text { nedeni }\end{array}$} & Bilgi sahibi olmamak & 32 & $41,97^{\mathrm{a}}$ & 5,61 & \multirow{4}{*}{$<0,001$} \\
\hline & İhtiyaç duymamak & 47 & $36,47^{b}$ & 7,47 & \\
\hline & Cekinmek/korkmak & 25 & $42,44^{\mathrm{a}}$ & 6,15 & \\
\hline & Risk altında görmemek & 6 & $37,17^{\mathrm{ab}}$ & 5,64 & \\
\hline \multicolumn{6}{|c|}{ Rahim Ăgzı Kanseri Önemseme/Ciddiyet } \\
\hline \multirow{4}{*}{$\begin{array}{l}\text { Yaptırmama } \\
\text { nedeni }\end{array}$} & Bilgi sahibi olmamak & 32 & 21,38 & 3,96 & \multirow{4}{*}{0,963} \\
\hline & İhtiyaç duymamak & 47 & 21,26 & 4,09 & \\
\hline & Çekinmek/korkmak & 25 & 21,60 & 4,42 & \\
\hline & Risk altında görmemek & 6 & 20,67 & 3,20 & \\
\hline \multicolumn{6}{|c|}{ Rahim Ăgzı Kanseri Duyarlılık } \\
\hline \multirow{4}{*}{$\begin{array}{c}\text { Yaptırmama } \\
\text { nedeni }\end{array}$} & Bilgi sahibi olmamak & 32 & 6,91 & 1,30 & \multirow{4}{*}{0,897} \\
\hline & İhtiyaç duymamak & 47 & 6,70 & 1,43 & \\
\hline & Çekinmek/korkmak & 25 & 6,84 & 1,18 & \\
\hline & Risk altında görmemek & 6 & 7,00 & 1,55 & \\
\hline \multicolumn{6}{|c|}{ Rahim Ă̆zı Kanseri Sağlık Motivasyonu } \\
\hline \multirow{4}{*}{$\begin{array}{l}\text { Yaptırmama } \\
\text { nedeni }\end{array}$} & Bilgi sahibi olmamak & 32 & 8,31 & 1,69 & \multirow{4}{*}{0,370} \\
\hline & İhtiyaç duymamak & 47 & 8,43 & 1,98 & \\
\hline & Çekinmek/korkmak & 25 & 8,68 & 2,46 & \\
\hline & Risk altında görmemek & 6 & 9,83 & 1,60 & \\
\hline
\end{tabular}

: Pap smear testi yaptırmayan ve nedenini belirten 110 kişi bulunmaktadır.

\section{TARTIŞMA}

Literatürde kadınların serviks kanseri ve taramasıyla ilgili sağlık inançlarını değerlendiren çok sayıda çalışma bulunmaktadır. Farklı ülkelerde yapılmış çalışmalarda serviks kanseri ve Pap smear testini bilme durumları açısından katılımcılar arasında farklılıklar olduğu görülmektedir. Çalışmamızda katılımcıların yarısında fazlasının serviks kanseri ve Pap smear testi hakkında bilgisi bulunmaktadır. Çalışmamıza benzer şekilde Önal ve arkadaşlarının ve Kürtüncü ve arkadaşlarının yaptığg çalışmalarda katılımcıların çoğunluğunun pap smear testini bildiğini bildirmişlerdir $(6,7)$. Buna karşılık pap smear testi hakkında daha düşük oranda bilgi ve farkındalık olan çalışmalar da mevcuttur $(8,9)$. Çalışmaların yapıldığı tarih, yer ve kurumlar ile katılımcıların yaş, eğitim düzeyi, meslek gibi sosyodemografik özelliklerinin bu farklılıkların oluşmasında etkili olabileceğini düşünmekteyiz.

Çalışmada serviks kanseri ve Pap smear testi hakkında bilgisi olduğunu ifade eden katılımcıların çoğunluğunun bilgi kaynağının sağlık personeli olduğunu ifade etmiştir. Literatürdeki çalışmalara bakıldığında çalışmamızla benzer sonuçlar bulunmuştur. Çetişli ve arkadaşlarının (9) İzmir'de yaptığı çalışmada katılımcıların \%61,9'u, İnan'ın (10) Diyarbakır'da yaptığı çalışmada ise \%94,3'ü sağlık personelinden bilgi aldığını belirtmişlerdir. Yurt 
dışı literatür tarandığında Tabeshian ve arkadaşlarının (11) yaptığı çalışmada Ashtarian ve arkadaşlarının (12) yaptığı çalışmada ve Chang'ın (13) yaptığı çalışmada bilgi kaynağı olarak en çok sağlık personellerinin kilit rol oynadığı bildirilmiştir. Tüm bu çalışmalardaki verilerde de görüldüğü üzere kadınların serviks kanseri ve taraması hakkında bilgi düzeyi ve farkındalığını artırmak en çok sağlık personellerine düşmektedir. $\mathrm{Bu}$ doğrultuda kadınların serviks kanseri hakkındaki bilgi düzeylerinin belirlenmesi, taramanın planlanması ve uygulanması konusunda sağlık personellerinin daha etkin rol almasının yararlı olacağı düşünülmektedir. Katılımcıların Pap smear testini yaptırmama nedenlerine göre dağılımlarına bakıldığında dörtte biri test hakkında bilgi sahibi olmadığı için, beşte birinin de muayeneden çekindiği için Pap smear testi yaptırmadığını belirtmiştir. Bilgisi olmadığı için testi yaptırmadığını ifade eden katılımcılar diğer çalışmalarda da dikkat çekmektedir $(10,14)$.

Literatür incelendiğinde Güvenç'in (15) çalışmasında kadınların ihtiyaç hissetmediği için, Nazilli'nin (16) çalışmasında gerek duymadığı için ve muayene olmaktan çekindiği için, Demirgöz Bal'ın (17) Karaman'da yaptığı çalışmada ise şikayeti olmadığı için pap smear testini yaptırmadıkları belirtmişlerdir. Sonuçların farklı nedenler belirtilmesinde sosyodemografik, sosyokültürel ve sosyoekonomik farklılıkların, dini inanç ve hassasiyetlerin etkili olabileceğini düşünmekteyiz.

Çalışmamızda yer alan katılımcıların Pap smear testini yaptırma nedenlerine göre dağılımlarına bakıldığında 3 'te birinin doktor önerisiyle testi yaptırdığını ifade etmiştir. Buna karşılık test yaptıranların yarısı bir şikayetleri olması üzerine test yaptırdığını belirtmiştir. Literatür incelendiğinde Baran'ın (18) Diyarbakır'da yaptığ çalışmada kadınların \%45'i doktor istemi nedeniyle, Karaoğlan'ın (19) yaptığı 47 çalışmada \%63,23'ü doktor önerisiyle testi yaptırdığını ifade etmiştir. Oransal olarak çalışmalar arasında fark bulunmasına rağmen kadınların testi yaptırma konusunda en çok doktor önerisi ve jinekolojik rahatsılıklardan etkilendikleri görülmektedir. Katılımcıların ailesinde/çevresinde serviks kanseri olma durumlarına göre Pap smear testi yaptırma oranları incelendiğinde, ailesinde/çevresinde serviks kanseri olan ve olmayan katılımcılar arasında istatiksel olarak anlamlı ilişki saptanmıştır. Ailesinde/çevresinde serviks kanseri olan katılımcıların olmayanlara göre daha fazla Pap smear testi yaptırdığı görülmüştür. Literatür incelendiğinde çalışmamıza benzer şekilde, Oran Tuna ve arkadaşlarının yaptığı çalışmada ailesinde serviks kanseri olanlar ve olmayanlar arasında istatiksel olarak anlamlı ilişki saptanmıştır (20).

Çalışmanın bu bulgusundan farklı olarak Özçam ve arkadaşlarının (21) İstanbul'da, Büyükkayacı Duman ve arkadaşlarının (22) Çorum'da, ve İnan'ın (10) Diyarbakır'da yaptığı çalışmada ailesinde serviks kanseri olanlar ve olmayanlar arasında anlamlı istatistiksel farklılık saptanmamıştır. $\mathrm{Bu}$ çalışmalarda ailesinde serviks kanseri öyküsü olan katılımcı sayısının az olmasının farklılığın belirlenmesini engellemiş olabileceği düşünülebilir. Yurt dişında yürütülen çalışmalar incelendiğinde ise; Parsa ve arkadaşlarının (23) çalışmasında ailesinde serviks kanseri öyküsü olan bireylerin daha fazla Pap smear testi yaptırdığı bildirilmiş olup, Mohammadi ve arkadaşlarının (24) çalışmasında ise ailesinde serviks kanseri öyküsünün olmasının testi yaptırmada etkisi olmadığı bildirilmiştir.

\section{Araştırmanın Sınırlılıkları}

Araştırmanın sonuçları sadece çalışmaya katılan katılımcilardan elde edilen bilgiler ile sınırlıdır, genelleme yapılamaz. Araştırmaya, sadece evli/boşanmış olan kadınlar alınmıştır. Gebe kadınlar araştırma kapsamına dahil edilmemiştir. Sadece hastaneye başvuran kadınlar ile yapılmış olması araştırmanın sinırlıliklarındandır.

\section{SONUÇ}

Çalışmamızın sonuçlarına göre katılımcıların çoğunun pap smear testi hakkında bilgi sahibi olmasına rağmen test yaptıranların nispeten az olduğu belirlenmiştir. Yine çalışma sonuçlarına göre pap smear tarama testi yaptıranların yarısının bir şikayet üzerine test yaptırmak istemesi, ancak az bir kısmının doktor tavsiyesi ile test yaptırması; koruyucu hekimlik açısından geliştirilmesi gereken bir durumdur. Aile sağlığı merkezlerine gelen her uygun yal aralığındaki hastaya serviks ağzı kanseri erken taranması açısından rehberlik ve danışmanlık yapılması teşvik edilmelidir.

Yazarların Katkıları: Fikir/Kavram: Z.G.; Tasarım: Z.G.; Veri Toplama ve/veya İşleme: G.U.; Analiz ve/veya Yorum: Z.G., M.A.S.; Literatür Taraması: G.U.; Makale Yazımı: G.U., Z.G.; Eleştirel İnceleme: Z.G.

\section{KAYNAKLAR}

1. WHO. Global Cancer Observatory [Internet]. [Updated: 2018; Cited: 2018 Mar 19]. Available from: http://gco.iarc.fr/

2. hsgm.saglik.gov.tr [Internet]. Kanser Erken Teşhis, Tarama ve Eğitim Merkezi El Kitabı. T.C. Sağlık Bakanlığı Kanserle Savaş Dairesi Başkanlığı [Erişim tarihi: 04.04.2019]. Erişim adresi: https://hsgm.saglik.gov.tr/depo/birimler/kanserdb/yayinlar/Kitaplar/KETEM_EL_KiTABi.pdf

3. Ak M, Canbal M, Turan S, Gürbüz N. Aile hekimliği polikliniğine başvuran kadınlarda pap smear testinin farkındalığının değerlendirilmesi. Konuralp Tıp Derg. 2010; 2(2): 1- 4 .

4. Champion VL, Skinner CS. The Health Belief Model. Glanz K, Rimer BK, Viswanath K, editors. Health behavior and health education: theory, research, and practice. 4nd ed. San Francisco: Jossey-Bass; 2008.

5. Guvenc G, Akyuz A, Açikel CH. Health belief model scale for cervical cancer and pap smear test: psychometric testing. J Adv Nurs. 2011; 67(2): 42837.

6. Önal B, Alp Yılmaz F. Kadınların sağlık sorumluluğu ile serviks kanseri erken tanısına yönelik tutumları arasındaki ilişkinin belirlenmesi [Yüksek Lisans Tezi]. Yozgat: Yozgat Bozok Üniversitesi-Kırıkkale Üniversitesi Sağlık Bilimleri Enstitüsü Hemşirelik Anabilim Dalı; 2018.

7. Kürtüncü M, Arslan N, Alkan I, Bahadır Ö, Bahadır Ö. 10-15 yaş arası kız çocuğu olan annelerin rahim ağzı kanseri ve HPV aşısı konusunda bilgi, tutum ve davranışları. J Hum Sci. 2018; 15(2):1072-85.

8. Kızılırmak A, Kocaöz S. Bir Üniversitedeki Kadınların serviks kanseri ve pap smear testine ilişkin 
sağlık inançlarını etkileyen faktörler. STED / Sürekli Tıp Eğitimi Derg. 2018; 27(3): 165-75.

9. Cetisli NE, Top ED, Işık G. Cervical cancer and pap smear test health beliefs and health-promoting lifestyle of women in Turkey. Int J Caring Sci. 2016; 9(2): 630-9.

10. İnan E, Ceylan A. Diyarbakır İli Kayapınar İlçesi 9 nolu aile sağlık merkezi bölgesinde 30-69 yaş arası kadınların meme ve serviks kanseri konusunda bilgi, tutum ve davranışlarının değerlendirilmesi [Tıpta Uzmanlık tezi]. Diyarbakır: Dicle Üniversitesi Tıp Fakültesi Halk Sağlığı Anabilim Dalı; 2018.

11. Tabeshian A, Firozeh F. The effect of health education on performing Pap smear test for prevention of cervix cancer in teachers of Isfahan city. Med Sci J Islam Azad Univesity - Tehran Med Branch. 2009; 19(1): 35-40.

12. Ashtarian H, Mirzabeigi E, Mahmoodi E, Khezeli M. Knowledge about cervical cancer and pap smear and the factors influencing the pap test screening among women. Int J Community Based Nurs Midwifery. 2017; 5(2): 188-95.

13. Chang CC, Tseng CJ, Liu WW, Jain S, Horng SG, Soong YK, et al. Clinical evaluation of a new model of self-obtained method for the assessment of genital human papilloma virus infection in an underserved population. Chang Gung Med J. 2002; 25(10): 66471.

14. Çelik OG, Malak AT, Öztürk Z, Yılmaz D. Analysis on the condition of women in postmenopausal period on their application of breast self-examination and having mammography and pap smear screening. Anatol J Clin Investig. 2009; 3(3): 159-63

15. Güvenç G. Serviks kanseri hakkında farkındalık arttırmaya yönelik geliştirilen yöntemin kadınların pap smear yaptırmalarına etkisi [Doktora Tezi]. Ankara: Gülhane Askeri Tıp Akademisi Sağlık Bilimleri Enstitüsü, Kadın Hastalıkları ve Doğum Hemşireliği Bilim Dalı; 2008.

16. Nazilli B. Hemşire ve ebelerin rahim ağzı kanseri ve pap smear testi ile ilgili sağlık inançları [Yüksek Lisans Tezi]. İstanbul: Okan Üniversitesi Sağlık Bilimleri Enstitüsü, Hemşirelik Anabilim Dalı; 2017.

17. Demirgöz BM. Kadınların Pap smear testi yaptırma durumlarının sağlık inanç modeli ölçeği ile değerlendirilmesi. J Marmara Univ Inst Heal Sci. 2014; 4(3): 133-8.

18. Baran M. Meme ve serviks kanseri konusunda kadınların bilgi ve bilinç düzeyleri [Yüksek Lisans Tezi]. İstanbul: Beykent Üniversitesi Sosyal Bilimler Enstitüsü; 2013.

19. Karaoğlan D. Kadınların serviks kanser risk faktörleri ve erken tanı yöntemlerine ilişkin bilgi ve uygulamalarını belirlenmesi [Yüksek Lisans Tezi]. Lefkoşa: Yakın Doğu Üniversitesi Sağlık Bilimleri Enstitüsü; 2016.

20. Tuna Oran N, Ozturk Can H, Senuzun Aykar F. Health Promotion lifestyle and cancer screening behaviors: a survey among academician women. Asian Pacific J Cancer Prev. 2008; 9(3): 15-8.

21. Ozcam H, Cimen G, Uzuncakmak C, Aydin S, Ozcan $\mathrm{T}$, Boran B. Evaluation of the knowledge, attitude, and behavior of female health workers about breast cancer, cervical cancer, and routine screening tests. Istanbul Med J. 2014; 15(3): 154-60.

22. Büyükkayacı DN, Yüksel KD, Albayrak SA. Kırk Yaş üstü kadınların meme ve serviks kanseri taramalarına yönelik bilgi ve uygulamaları G.O.P. Taksim E.A.H. Jaren. 2015; 1(1): 30-8.

23. Parsa P, Sharifi F, Shobeiri F, Karami M. Effects of group counseling based on health belief model on cervical cancer screening beliefs and performance of rural women in Kaboudrahang, Iran. Asian Pac J Cancer Prev. 2017; 18(6): 1525-30.

24. Mohammadi S, Rejali M, Mostajeran M, Yadegarfar G. The study of relationship between risk factors for cervical cancer and knowledge and attitude of health workers toward pap smear in Isfahan and its comparison with Chaharmahal and Bakhtiari Province, Iran. Int J Cancer Manag. 2019; 12(4); e85357. doi: 10.5812/ijcm.85357. 